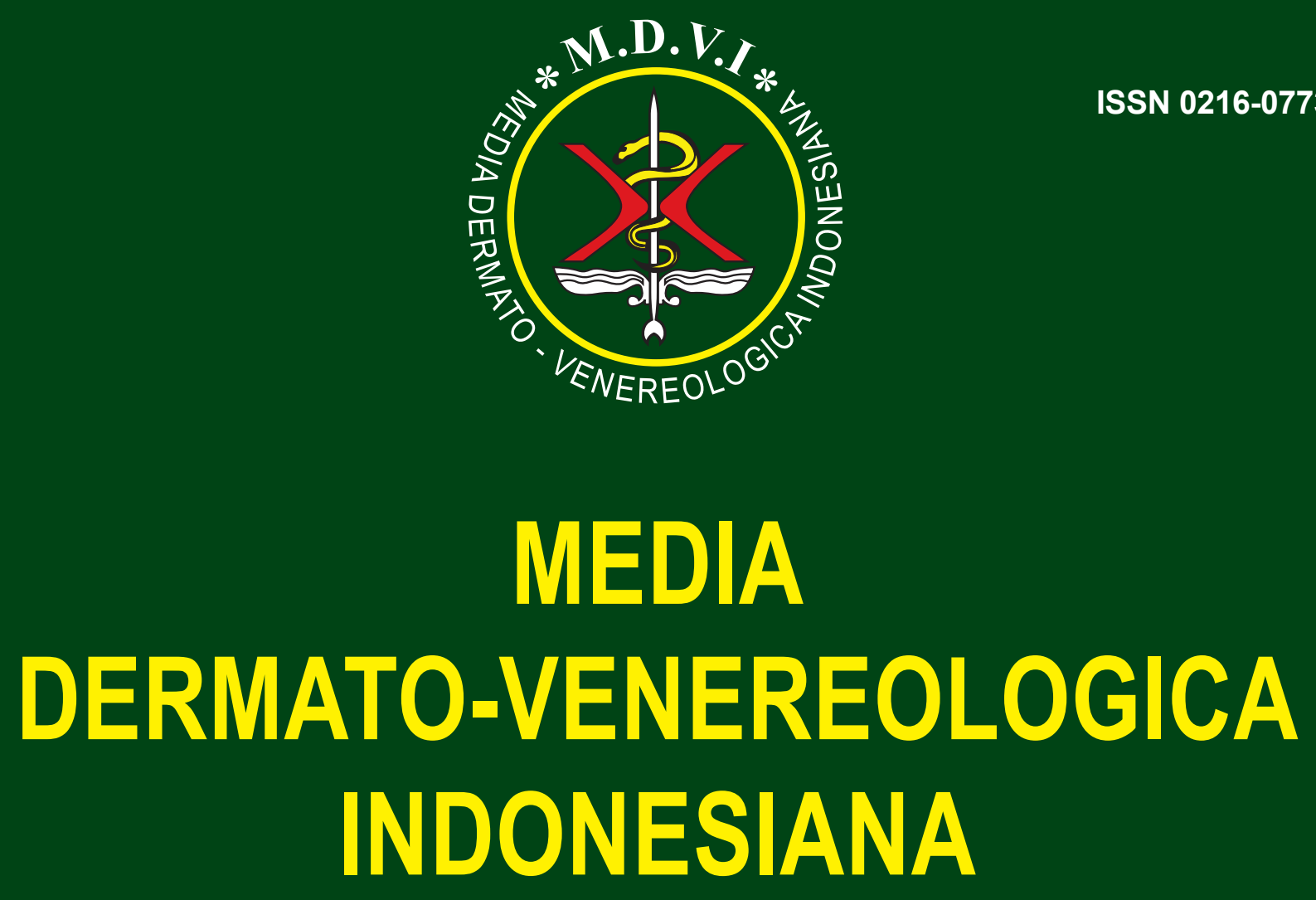

Editorial : Trias epidemiologis : Pendekatan memahami orkestra sistem imunologi kulit

Uji klinis sampo formulasi khusus pada pasien ketombe dan dermatitis seboroik ringan pada skalp

Tingkat pengetahuan dan sikap pekerja binatu terhadap dermatitis kontak

Korelasi antara kadar superoksida dismutase dengan malondialdehid pada jaringan keratosis seboroik

Psoriasis vulgaris berat diterapi mikofenolat mofetil: tantangan dalam pengobatan

Terapi dapson pada pemfigoid bulosa

Modern wound dressing pada ulkus trofik pasien kusta tipe lepromatosa

Peningkatan enzim transaminase pada kusta

Korelasi gambaran histopatologi, teknik biopsi dan manifestasi klinis vaskulitis leukositoklastik kutan

Peran mikrobiom pada infeksi menular seksual

Melasma dalam sudut pandang genetik 


\title{
UJI KLINIS SAMPO FORMULASI KHUSUS PADA PASIEN KETOMBE DAN DERMATITIS SEBOROIK RINGAN PADA SKALP
}

\author{
Triana Agustin, * Githa Rahmayunita, * Rinadewi Astriningrum, * Eliza Miranda, * \\ Erdina HD Pusponegoro, * Arini Setiawati, ** Sandra Widaty* \\ *Departemen Ilmu Kesehatan Kulit dan Kelamin, \\ ${ }^{* *}$ Clinical Research Study Unit \\ FK Universitas Indonesia/RSUPN dr. Cipto Mangunkusumo, Jakarta
}

\begin{abstract}
ABSTRAK
Dermatitis seboroik (DS) merupakan kelainan inflamasi kulit di area seboroik berupa lesi eritematosa dan skuama, bersifat kronik-residif, sedangkan ketombe adalah DS derajat ringan berupa skuama pada skalp. Etiopatogenesis DS bersifat multifaktor, salah satunya berupa kolonisasi Malassezia. Studi pendahuluan ini menguji efikasi dan keamanan sampo dengan formulasi khusus yang mengandung climbazole 1\% dan piroctone olamine $0,75 \%$. Sebanyak 28 pasien ketombe dan 18 pasien DS ringan di skalp dibagi menjadi dua kelompok secara paralel, acak, dan tersamar ganda, yaitu kelompok uji dan kontrol. Kedua kelompok dilakukan pemeriksaan setiap 1 minggu selama 4 minggu. Efikasi dinilai menggunakan skor modifikasi Seborrheic Dermatitis Area and Severity Index (SDASI) dan penilaian pruritus menggunakan visual analogue scale (VAS). Analisis efikasi dilakukan secara intention-to-treat dan per-protokol.

Pada kelompok pasien ketombe, didapatkan penurunan skor modifikasi SDASI, luas lesi, derajat skuama yang berbeda bermakna antara kelompok uji dan plasebo $(p<0,05)$. Pada kelompok pasien DS ringan pada skalp, tidak didapatkan perbedaan yang bermakna pada penurunan skor modifikasi SDASI, luas lesi, derajat skuama, lesi eritematosa, dan skor lesi papul antara kelompok uji dan plasebo (p>0,05).

Sampo uji terbukti efektif mengobati ketombe, namun pada DS ringan di skalp sampo hanya efektif mengurangi jumlah skuama tetapi tidak mengurangi lesi inflamasi.
\end{abstract}

Kata kunci: climbazole, dermatitis seboroik, ketombe, piroctone olamine, sampo

\section{CLINICAL TRIAL OF SPECIALLY FORMULATED SHAMPOO ON PATIENTS WITH DANDRUFF AND MILD SCALP SEBORRHEIC DERMATITIS}

\begin{abstract}
Seborrheic Dermatitis (SD) is a chronic-recidive skin inflammatory disorder manifesting as erythematous lesions and scales, while dandruff is a mild SD. The etiopathogenesis is multifactorial, one of which is Malassezia colonization. This study aims to study the efficacy and safety of a specially formulated shampoo as SD management.

This preliminary study examined the efficacy and safety of a shampoo containing $1 \%$ climbazole and $0.75 \%$ piroctone olamine. Subjects, 28 dandruff patients and 18 mild scalp SD patients, were divided into two groups in parallel, randomized, double-blind methods, which were treatment and control group. Both groups were examined every week for 4 weeks. The efficacy was assessed by using modification of SD Area and Severity Index (SDASI) and pruritus was assessed by using visual analogue scale (VAS). Efficacy analysis was conducted with intention-to-treat and per protocol method.

There were significant differences in the reduction of modified SDASI score, lesion extension, scale degree in dandruff patients $(p<0.05)$ in contrast to $S D$ patients $(p>0.05)$. In $S D$ patients, there were no significant differences in erythema degree and papule score $(p>0.05)$.

The treatment shampoo is effective in managing dandruff; however, for mild scalp SD, it is only effective in reducing scales, not the inflammatory lesions
\end{abstract}

Keywords: climbazole, seborrheic dermatitis, dandruff, piroctone olamine, shampoo

Korespondensi:

Jl. Diponegoro 71, Jakarta Pusat

Tel: $021-31935383 /+62818832284$

E-mail: agustin.triana@yahoo.com 


\section{PENDAHULUAN}

Dermatitis seboroik (DS) merupakan inflamasi kulit yang bersifat kronik-residif di area seboroik, yaitu skalp, wajah (dahi, alis, lipat nasolabial, dan retro-aurikular) dan badan (presternal dan interskapula). ${ }^{1-5}$ Area lain yang terlibat adalah area lipatan (inguinal, inframamae, aksila), umbilikus, perineum dan anogenital. ${ }^{4-6}$ Ketombe merupakan kelainan kulit yang juga mengenai area seboroik. Ketombe lebih sering terjadi dibandingkan dengan DS, mengenai sekitar $50 \%$ populasi dewasa di seluruh dunia. ${ }^{7}$ Pada skalp, DS bervariasi dari ringan berupa pitiriasis sika (ketombe) hingga lesi eritematosa dengan skuama berminyak. ${ }^{1,8}$ Ketombe merupakan bentuk ringan DS. ${ }^{1}$ Kondisi dasar, manifestasi klinis, dan tata laksana DS dan ketombe sama. Perbedaan keduanya adalah ketombe hanya mengenai skalp berupa skuama disertai gatal, sedangkan DS dapat mengenai area seboroik lainnya dengan lesi skuama dan plak eritematosa disertai gatal. Skuama pada DS dan ketombe berwarna putih-kekuningan, berminyak, atau kering. ${ }^{9}$

Etiopatogenesis DS belum diketahui secara pasti. ${ }^{7,10}$ Etiologi DS bersifat multifaktor, dipengaruhi faktor endogen dan eksogen, yaitu interaksi antara sekresi glandula sebasea, kolonisasi Malassezia, kerentanan individu, dan abnormalitas sistem imun. ${ }^{1,6,7}$ Peran Malassezia dalam patogenesis DS didukung oleh korelasi positif antara kepadatan yeast dengan keparahan DS, perbaikan lesi DS setelah terapi anti jamur,serta rekurensi saat obat antijamur dihentikan dan rekolonisasi. ${ }^{1,2,6,10}$

Sampo digunakan untuk tata laksana DS di skalp dan ketombe. Sampo yang mengandung bahan aktif, antara lain zinc pyrithione, selenium sulfida, imidazole (misalnya ketoconazole, climbazole) dan piroctone olamine disarankan untuk tata laksana kelainan ini. Climbazole adalah anti jamur jenis imidazole yang bekerja dengan menghambat sintesis ergosterol. Efek samping yang mungkin timbul berupa kemerahan, ruam kulit, gatal, dan reaksi alergi.

Piroctone olamine adalah garam etanolamin dari N-hidroksipiridon yang tergolong dalam antimikotik hidroksipiridon. Piroctone olamine menghambat degradasi trigliserid menjadi asam oleat dan asam arakhidonat yang berperan dalam timbulnya ketombe akibat jamur. ${ }^{11}$ Pada DS derajat berat yang disertai skuama tebal perlu diberikan kortikosteroid topikal. Jika disertai inflamasi berat atau tidak membaik dengan pengobatan topikal, dapat diberikan kortikosteroid sistemik. ${ }^{6}$ Oleh karena penyebab DS dan ketombe bersifat multifaktor, peneliti ingin mengetahui peranan sampo berbahan aktif climbazole $1 \%$ dan piroctone olamine $0,75 \%$ untuk tata laksana DS ringan pada skalp dan ketombe

\section{METODE PENELITIAN}

Studi ini merupakan studi pendahuluan untuk mengetahui efikasi dan keamanan sampo yang mengandung climbazole $1 \%$ dan piroctone olamine $0,75 \%$ pada pasien ketombe dan DS skalp derajat ringan. Penelitian ini menggunakan dua kelompok paralel, acak, tersamar ganda, yaitu kelompok pasien dengan ketombe dan DS ringan pada skalp yang diberikan sampo uji dan sampo plasebo.

\section{Populasi Studi}

Besar sampel dihitung berdasarkan rumus perbedaan dua proporsi tidak berpasangan dengan perkiraan drop out $20 \%$, maka jumlah sampel adalah sebanyak 30 pasien ketombe dan 20 pasien DS ringan pada skalp.

Kriteria inklusi pada penelitian ini adalah subjek dengan tipe kulit Fitzpatrick III-IV, berusia 12-70 tahun, terdiagnosis klinis ketombe atau DS derajat ringan pada scalp, serta bersedia menjadi pasien penelitian dengan menandatangani formulir persetujuan (informed consent). Subyek tidak diikutsertakan dalam penelitian ini bila terdapat riwayat atau sedang mengalami penyakit pada skalp, riwayat penyakit gagal ginjal kronik, gangguan fungsi hati, psoriasis atau infeksi human immunodeficiency virus (HIV), sedang hamil atau menyusui, menggunakan kortikosteroid oral atau topikal, obat antijamur, isotretinoin, antihistamin serta riwayat hipersensitivitas tehadap bahan uji.

Setiap pasien menerima sampo plasebo untuk digunakan selama 3 hari washout period. Kemudian pasien menggunakan sampo produk uji atau plasebo sejumlah $7,5 \mathrm{~mL}$ (sesuai takaran) sekali sehari. Sampo digunakan dengan cara didiamkan atau dipijat selama 5-10 menit pada keadaan rambut basah. Selanjutnya pasien diperiksa setiap minggu ( \pm 1 hari) selama 4 minggu.

\section{Produk Uji}

Produk uji berupa sampo yang mengandung zat aktif climbazole $1 \%$ dan piroctone olamine 0,75\%. Komposisi plasebo serupa dengan sampo uji namun tanpa bahan aktif. Produk uji dan plasebo dibuat identik dalam hal warna, bau, dan kemasan. Produk uji dan plasebo dirandomisasi. Kedua strata pasien, yakni pasien dengan ketombe dan pasien dengan DS ringan pada skalp, masing-masing dirandomisasi secara blok dengan ukuran blok $=4$. 
Tabel 1. Komposisi sampo uji

\begin{tabular}{cll}
\hline No & \multicolumn{1}{c}{ Bahan Baku } & \multicolumn{1}{c}{ Fungsi } \\
\hline 1 & Dantuff C (Climbazole) & Bahan aktif \\
2 & Kopirox (Piroctone Olamine) & Bahan aktif \\
3 & Aloe Phytelen Colorless EG543 & Pelembap dan antiinflamasi \\
4 & D-Panthenol & Pelembap dan antiinflamasi \\
5 & Dissolvine Na2 & Bahan kelasi \\
6 & Montanox 20 & Pelarut \\
7 & Parfume Heiress & Parfum \\
8 & Menthol & Bahan pendingin \\
9 & Carbopol Aqua SF 2 Polymer & Menebalkan \\
10 & Dehyton K & Surfaktan \\
11 & Texapon NSO & Surfaktan \\
12 & Oramix NS 10 & Surfaktan \\
13 & Miranol Ultra L32 & Surfaktan \\
14 & Polycare Boost & Conditioning \\
15 & Jaguar excell & Conditioning \\
16 & Mirasheen Star NB & Pearlizing \\
17 & Aquadem & Pelarut \\
18 & Citric acid & Penyeimbang pH \\
19 & Caustic soda pearl & Penyeimbang pH \\
\hline
\end{tabular}

\section{Penilaian efikasi}

Efikasi sampo dinilai menggunakan skor modifikasi Seborrheic Dermatitis Area and Severity Index (SDASI), yang merupakan penilaian luas lesi dikalikan dengan hasil penjumlahan skor eritema, skuama, dan papul per kuadran area skalp, yang dibagi menjadi 4 kuadran. Ditetapkan derajat ringan bila rata-rata skor 1-9, derajat sedang 10-26, dan derajat berat $\geq 27$. Skor akan dihitung pada setiap kunjungan, yaitu baseline (H0), hari ke-7, 14 dan 28. Pada akhir kunjungan akan dinilai penurunan skor SDASI. Dinyatakan sembuh bila terdapat penurunan skor $\geq 70 \%$; perbaikan bila terdapat penurunan skor $50-69 \%$; perbaikan minimal bila terdapat penurunan skor $<50 \%$, dan gagal apabila tidak ada perbaikan atau memburuk. ${ }^{12}$ Dilakukan pula penilaian terhadap pruritus menggunakan visual analogue scale (VAS) $0-10$, dengan interpretasi skor $0=$ tidak ada keluhan pruritus; $1-3=$ pruritus ringan; $4-6=$ pruritus sedang; $7-8=$ pruritus berat; $\geq 9=$ pruritus sangat berat. ${ }^{13}$

\section{Analisis Statistik}

Analisis data efikasi sampo dilakukan secara intentionto-treat (ITT) dan per-protokol (PP). Penurunan skor eritema, skuama, luas area lesi, dan modifikasi SDASI setelah 28 hari pengobatan pada masing-masing kelompok dibandingkan dengan uji Wilcoxon, sedangkan penurunan skor kedua kelompok dibandingkan dengan uji Mann-Whitney. Penurunan pruritus berdasarkan VAS dibandingkan dengan menggunakan uji $\mathrm{T}$ berpasangan pada masing-masing kelompok dan menggunakan uji $\mathrm{T}$ antara kedua kelompok. Hasil dengan nilai $p<0,05$ dianggap bermakna secara statistik. Penelitian ini telah mendapat persetujuan Komite Etik Penelitian Kesehatan Fakultas Kedokteran Universitas Indonesia - RS. Dr. Cipto Mangunkusumo dengan nomor 123/UN2.F1/ETIK/2016.

\section{HASIL}

Total subjek yang diteliti sebanyak 50 subjek, terdiri atas 30 pasien ketombe dan 20 pasien DS ringan di skalp. Pada kelompok ketombe, 2 pasien tidak kontrol pada saat kunjungan hari ke-7 dan 1 pasien tidak kontrol pada saat kunjungan hari ke-21. Sementara itu, pada kelompok DS ringan di skalp, 2 pasien tidak kontrol saat kunjungan hari ke-14 dan 1 pasien dikeluarkan dari studi karena ditemukan pedikulosis kapitis pada kunjungan hari ke-14. Analisis efikasi secara ITT dilakukan terhadap 28 subjek pada kelompok ketombe, yang terdiri atas masing-masing 14 subjek pada kelompok uji dan plasebo. Selanjutnya, 18 pasien pada kelompok DS ringan di skalp, terdiri atas 8 orang pada kelompok uji dan 10 orang pada kelompok plasebo.

Pada kelompok uji pasien ketombe, didapatkan rentang usia sebesar 18-45 tahun, rerata usia 30,9 tahun dengan simpang baku 8,87 tahun. Pada kelompok plasebo pasien ketombe, didapatkan rentang usia sebesar 19-55 tahun dan rerata 32,1 dengan simpang baku 12,15 tahun. Pada kelompok uji pasien DS ringan di skalp, didapatkan rentang usia 24-48 tahun dan rerata 34,3 dengan simpang baku 8,17 tahun. Pada kelompok plasebo pasien DS ringan di skalp, didapatkan rentang usia 12-38 tahun dan rerata 25,3 dengan simpang baku 7,13 tahun.

Pada studi ini, didapatkan penurunan yang bermakna pada rerata total skor modifikasi SDASI, luas lesi, dan derajat skuama. Rerata total skor modifikasi SDASI, luas lesi ketombe, dan derajat skuama pada pasien ketombe kelompok uji dan plasebo ditampilkan pada Gambar 1. Apabila dibandingkan antara kelompok uji dan plasebo, terdapat perbedaan penurunan rerata total skor modifikasi SDASI $(\mathrm{p}=0,003)$, penurunan rerata luas lesi $(\mathrm{p}=0,01)$, dan penurunan rerata derajat skuama yang bermakna secara statistik $(\mathrm{p}=0,007)$; penurunan yang dialami kelompok uji lebih besar dibandingkan kelompok plasebo. (Gambar 1). 

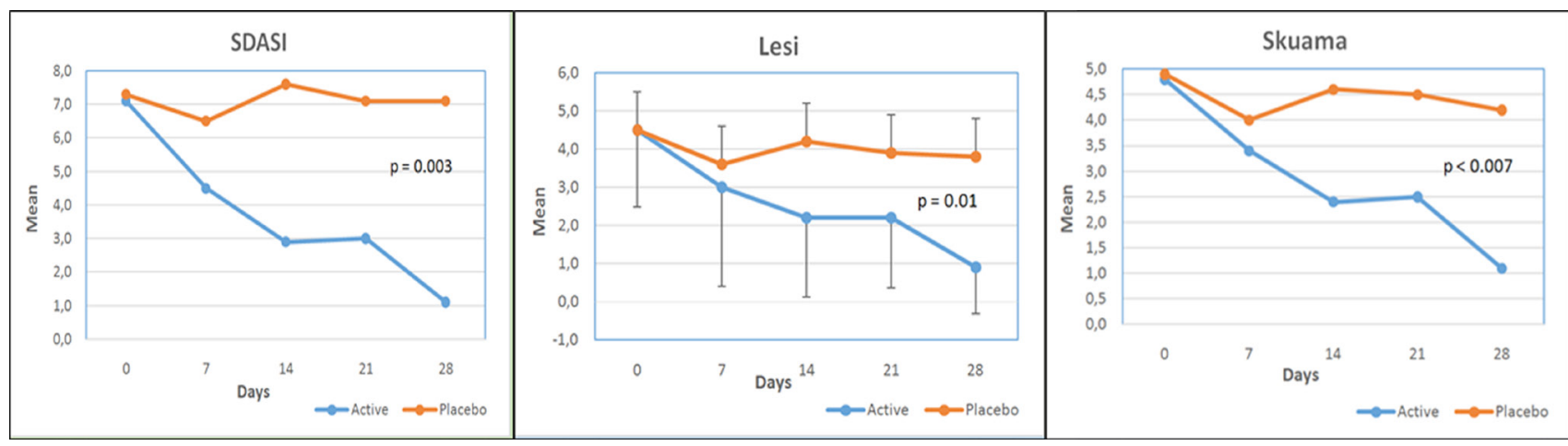

Gambar 1. Rerata skor modifikasi SDASI, luas lesi, dan derajat skuama pada kelompok pasien ketombe

Rerata total skor modifikasi SDASI, luas lesi, dan derajat skuama pada pasien DS ringan pada skalp kelompok uji dan plasebo ditampilkan pada gambar 2. Apabila dibandingkan antara kelompok uji dan plasebo, tidak terdapat perbedaan penurunan rerata total skor modifikasi SDASI $(\mathrm{p}=0,50)$, penurunan rerata luas lesi yang bermakna secara statistik $(\mathrm{p}=0,16)$, dan penurunan rerata derajat skuama $(\mathrm{p}=0,12)$ yang bermakna secara statistik (Gambar 2).
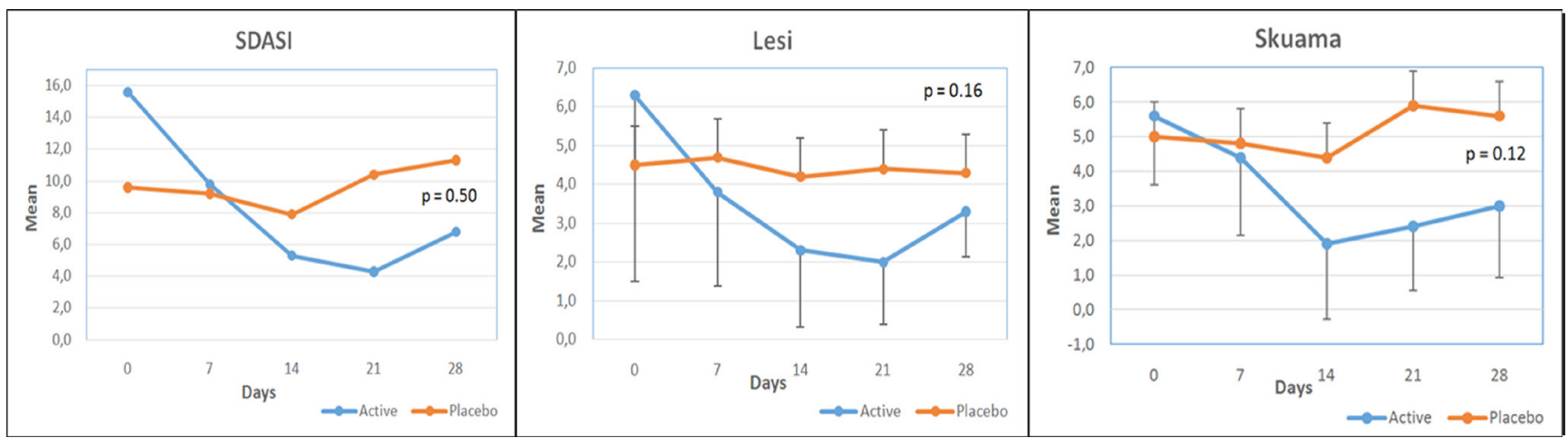

Gambar 2. Rerata skor modifikasi SDASI, luas lesi, dan derajat skuama pada kelompok pasien DS derajat ringan

Rerata skor lesi eritematosa dan skor lesi papul pada pasien DS ringan pada skalp kelompok uji dan plasebo ditampilkan pada gambar 3. Apabila dibandingkan antara kelompok uji dan plasebo, tidak terdapat perbedaan penurunan rerata skor lesi eritematosa $(\mathrm{p}=0,59)$ dan penurunan rerata skor lesi papul yang bermakna secara statistik $(\mathrm{p}=0,29)$. (Gambar 3)

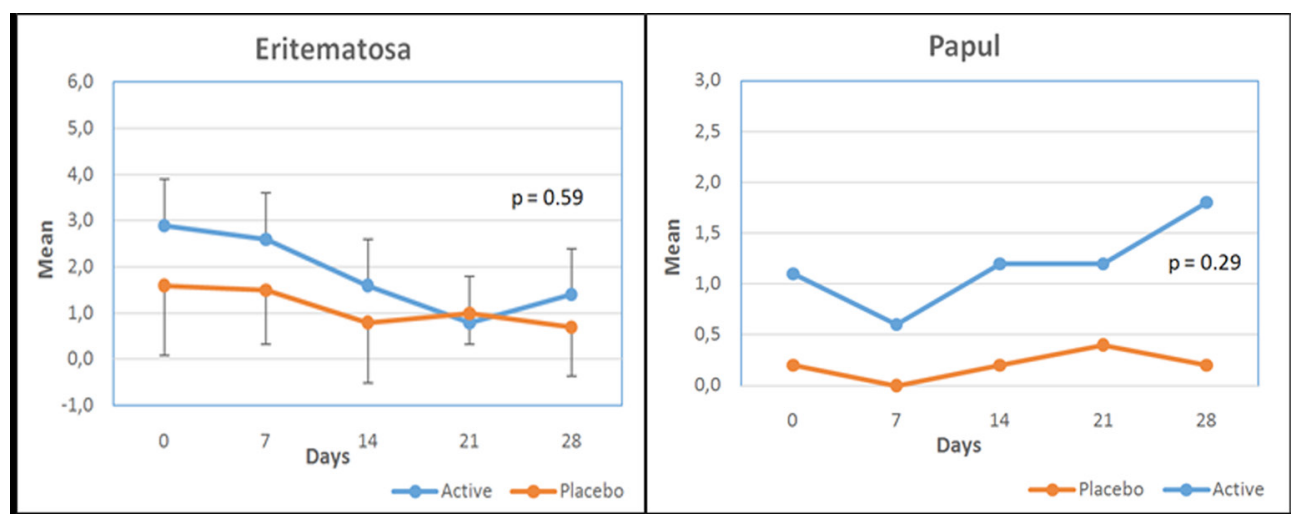

Gambar 3. Rerata skor lesi eritematosa dan lesi papul pada kelompok pasien DS ringan di skalp

Keparahan keluhan subjektif rasa gatal dinilai menggunakan VAS. Pada pasien ketombe, terdapat penurunan rerata skor VAS yang bermakna secara statistik pada kelompok uji $(\mathrm{p}=0,001)$, sama halnya pada kelompok plasebo, terjadi penurunan rerata 
skor VAS pada hari ke-28, namun perbedaan antar keduanya tidak bermakna $(\mathrm{p}=0,06)$. Apabila dibandingkan antara kelompok uji dan plasebo, terdapat penurunan skor VAS yang lebih besar pada kelompok uji yang bermakna secara statistik $(\mathrm{p}=0,04) .($ Gambar 4)

Pada pasien DS ringan di skalp, terdapat penurunan rerata skor VAS pada kelompok uji, namun tidak bermakna secara statistik $(\mathrm{p}=0,08)$. Sedangkan pada kelompok plasebo, terjadi penurunan rerata skor VAS pada hari ke-28 yang bermakna secara statistik $(\mathrm{p}=0,001)$. Apabila dibandingkan antara kelompok uji dan plasebo, didapatkan perbedaan penurunan skor VAS yang tidak bermakna secara statistik dengan $\mathrm{p}=0,11$ (Gambar 4).

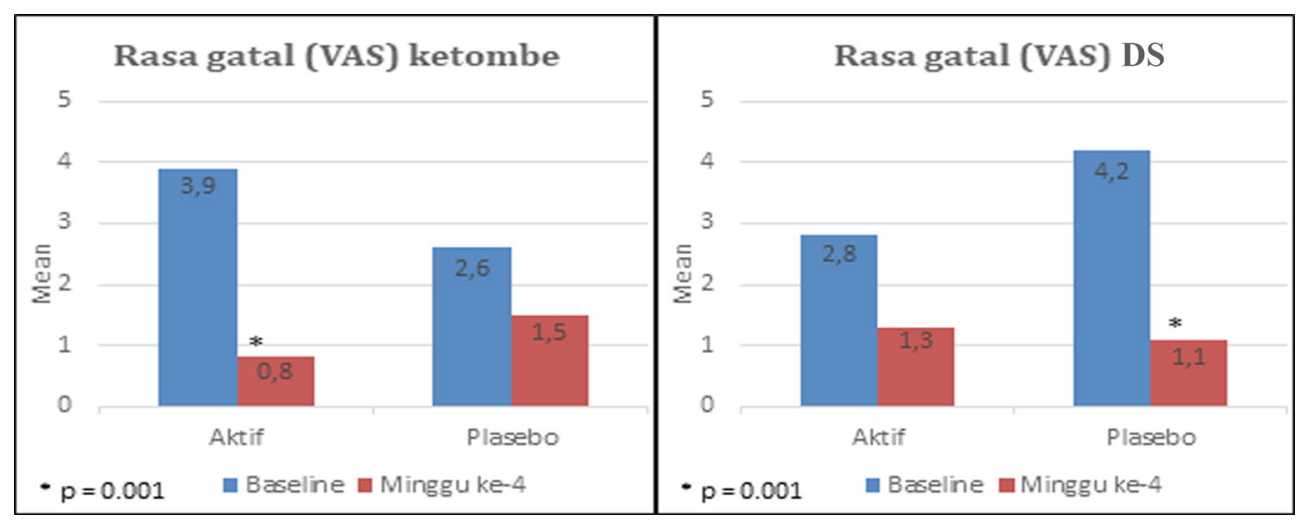

Gambar 4. Rerata skor VAS pada kelompok pasien ketombe dan DS ringan pada skalp

\section{DISKUSI}

Pada studi ini, secara keseluruhan sampo uji terbukti efektif untuk digunakan pada pasien ketombe, yaitu dalam hal penurunan jumlah skuama, luas lesi, penurunan total skor modifikasi SDASI, dan efektivitasnya berbeda bermakna dibandingkan dengan sampo plasebo (plasebo tidak efektif). Sampo uji juga terbukti lebih efektif untuk mengurangi gatal di skalp dibandingkan sampo plasebo (plasebo juga sedikit lebih efektif untuk gatal). Hasil ini serupa dengan studi lain oleh Scdhmidt-Rose dkk. yang membandingkan pemakaian sampo yang mengandung kombinasi piroctone olamine/climbazole dengan zinc pyrithione 3 kali seminggu selama 4 minggu pada kasus ketombe derajat sedang dan berat. Studi tersebut menyimpulkan bahwa sampo yang mengandung kombinasi piroctone olamine/climbazole efektif dan menyebabkan penurunan jumlah ketombe yang bermakna dari baseline hingga minggu ke-4 $(\mathrm{p}<0,01){ }^{14}$

Pada studi ini, 78,6\% pasien kelompok uji dan 28,6\% pasien kelompok plasebo pada subjek ketombe mengalami kesembuhan (perbaikan $\geq 70 \%$ ). Hal ini serupa dengan studi oleh Rastegar dkk. yang membandingkan efektivitas antara sampo yang mengandung climbazole dengan piroctone olamine dengan penggunaan 3 kali seminggu selama 5 minggu. Studi tersebut mendapatkan $80 \%$ pasien kelompok climbazole dari 60 pasien dengan ketombe derajat sedang mengalami kesembuhan, dan $20 \%$ pasien mengalami perbaikan dari derajat sedang menjadi ringan, dibandingkan dengan kelompok piroctone olamine yaitu 55\% pasien mengalami kesembuhan dan $45 \%$ pasien mengalami perbaikan menjadi derajat ringan. Penyembuhan ketombe lebih baik pada kelompok climbazole dibandingkan kelompok piroctone olamine $(\mathrm{p}<0,01){ }^{15}$

Pada pasien DS ringan pada skalp, sampo uji efektif untuk memperbaiki skuama, sedangkan plasebo sama sekali tidak efektif, bahkan memburuk. Akan tetapi perbaikan skuama oleh sampo uji tidak bermakna secara statistik dibandingkan dengan plasebo. Sampo uji juga dapat memperbaiki lesi eritematosa, namun plasebo sedikit lebih efektif untuk hal ini, sehingga disimpulkan bahwa sampo uji tidak lebih baik dibandingkan plasebo. Sampo uji memperburuk lesi papul, sedangkan plasebo tidak menyebabkan efek pada lesi papul. Secara keseluruhan, sampo uji lebih efektif untuk DS ringan di skalp secara klinis (hampir mencapai kemaknaan statistik) dibandingkan plasebo, namun tidak terdapat perbedaan yang bermakna antara sampo uji dan plasebo. Pada kelompok pasien ketombe, terdapat penurunan skor VAS yang lebih besar pada kelompok uji yang bermakna secara statistik. Sedangkan pada kelompok pasien DS ringan pada skalp, didapatkan perbedaan penurunan skor VAS yang tidak bermakna secara statistik.

Studi yang dilakukan oleh Ashtiani dkk. menilai efektivitas sampo cepigene yang mengandung bahan natural dibandingkan dengan sampo ketokonazol dan plasebo pada kasus ketombe dan DS skalp. Evaluasi dilakukan saat baseline, minggu ke-3 dan ke-7 terhadap penurunan jumlah skuama berdasarkan adherent scalp flake scoring (ASFS). Subjek yang mendapatkan sampo cepigene mengalami penurunan jumlah skuama dan gatal yang signifikan dibandingkan skor baseline, demikian pula dengan kelompok ketokonazol dibandingkan dengan kelompok plasebo. Rerata penurunan skor ASF pada pasien ketombe dan DS skalp pada kelompok sampo ketokonazol dan cepigene adalah $8 \%$ dan $10 \%$ pada minggu ke-2; $16 \%$ dan $32 \%$ pada minggu ke- $4 ; 43 \%$ dan $80 \%$ pada minggu ke- 
6; serta $48 \%$ dan $89 \%$ pada minggu ke-7. Pada kelompok plasebo setelah minggu ke-7 hanya terdapat penurunan sebesar $10 \%$ dan tidak efektif. ${ }^{16}$ Pada studi ini, didapatkan hanya $25 \%$ pasien kelompok uji dan 30\% kelompok plasebo pada kelompok DS skalp yang mengalami kesembuhan (perbaikan $\geq 70 \%$ ). Hal ini kemungkinan disebabkan oleh kandungan sampo cepigene, yaitu piroctone olamine dan beberapa bahan antiinflamasi seperti tea tree oil, rosemary, lavender, salvia officinalis, ekstrak willow, aloe vera, ekstrak marshmallow dan asam salisilat yang merupakan keratolitik. ${ }^{16}$ Pada studi ini, kandungan antiinflamasi yang terdapat pada sampo uji lebih sedikit, yaitu Aloe Phytelen dan D-Panthenol, sedangkan pada studi Ashtiani dkk. tidak dibedakan antara kelompok ketombe dan DS skalp.

Efek samping yang didapatkan akibat pemakaian sampo baik pada sampo uji maupun sampo plasebo pada pasien ketombe dan DS ringan pada skalp, berupa efek samping ringan, seperti keluhan gatal yang bertambah, rasa perih, rasa panas, rambut kering, rambut kusut, rambut rontok, dan rambut berminyak.

\section{SIMPULAN}

Sampo uji efektif untuk mengobati ketombe dengan mengurangi jumlah skuama dan mengurangi rasa gatal di skalp, sedangkan untuk DS ringan pada skalp, sampo uji efektif dalam hal mengurangi jumlah skuama, namun kurang efektif terhadap perbaikan lesi inflamasi (lesi eritematosa dan papul). Hal ini kemungkinan disebabkan oleh sedikitnya bahan antiinflamasi yang terdapat dalam sampo tersebut.

\section{DAFTAR PUSTAKA}

1. Dessinioti C, Katsambas A. Seborrheic dermatitis: Etiology, risk factors, and treatments: Facts and controversies. Clin Dermatol. 2013;31(4):343-51.

2. Mokos ZB, Kralj M, Basta-Juzbasic A, Jukic IL. Seborrheic dermatitis: An update. Acta Dermatovenereol Croat. 2012;20(2):98-104.

3. Gelmetti CM, Grimalt R. Infantile seborrhoeic dermatitis. Dalam: Irvine AD, Hoeger PH, Yan AC, penyunting. Harper's Textbook of Pediatric Dermatology. Edisi ke-3. Oxford: Blackwell;2011.h.35.1-8.

4. Cheong WK, Yeung CK, Torsekar RG, Suh DH, Ungpakorn R, Widaty S, dkk. Treatment of seborrhoeic dermatitis in Asia: A consensus guide. Skin Appendage Disord. 2015;1(4):187-96.
5. Veraldi S, Raia DD, Barbarfeschi M. Ethiopathogenesis. Dalam: Micali G, Veraldi S, Cheong WK, Suh DH, penyunting. Seborrheic Dermatitis.Edisi ke-1. India: MACMILLAN;2015.h.15-7.

6. Collins CD, Hivnor C. Seborrheic Dermatitis. Dalam:Goldsmith LA, Katz SI, Gilchrest BA, Paller AS, Leffel DJ, Wolff K, penyunting. Fitzpatrick's Dermatology in General Medicine. Edisi ke-8. Palatino: McGraw-Hill; 2012.h.259-66.

7. Borda LJ, Wikramanayake TC. Seborrheic dermatitis and dandruff: A comprehensive review. J Clin Invest Dermatol. 2015;3(2):1-7.

8. Musumeci ML, Verzi AE, Pulvirenti N, Micali G. Clinical Aspects. Dalam: Micali G, Veraldi S, Cheong WK, Suh DH, penyunting. Seborrheic Dermatitis. Edisi ke-1. India: MACMILLAN;2015.h.21-6.

9. Monfrecola G, Marasca C. Epidemiology. Dalam: Micali G, Veraldi S, Cheong WK, Suh DH, penyunting. Seborrheic Dermatitis, Edisi ke-1. India: MACMILLAN;2015.h.9-11.

10. Clark GW, Pope SM, Jaboori KA. Diagnosis and treatment of seborrheic dermatitis. Am Fam Physician.2015;91(3):185-9.

11. Narshana M, Ravikumar P. An overview of dandruff and novel formulations as a treatment strategy. IJPSR. 2017;9(2):417-31.

12. Schwartz JR. A comprehensive pathophysiology of dandruff and seborrheic dermatitis - towards a more precise definition of scalp health. Acta Derm Venereol. 2013;93(2):131-7.

13. Reich A, Heisig M, Phan NQ, Taneda K, Takamori K, Takeuchi S, dkk. Visual Analog Scale: Evaluation of the instrument for the assessment of pruritus. Acta Derm Venereol.2012;92(5):497-501.

14. Schmidt-rose T, Braren S, Folster H, Hillemann T, Oltrogge B, Philipp P, dkk. Efficacy of a piroctone olamine/climbazole shampoo in comparison with a zinc pyrithione shampoo in subjects with moderate to severe dandruff.Int $\mathrm{J}$ Cosmet Sci.2011;33(3):276-82.

15. Rastegar H, Ashtiani HA, Baghaei M, Ehsani A, Noor mohammad pour P, Aqzizahari S, dkk. A comparison of clinical efficacy between a basic shampoo with herbal extracts containing climbazole and its similar sample containing piroctone olamine in the treatment of dandruff and seborrheic dermatitis. Iran J Dermatol. 2009;12(3):82-5.

16. Ashtiani HA, Rastegar H, Aghaei M, Ehsani A, Barikbin B, Salout MH, dkk. Clinical efficacy of natural formulated shampoo in subjects with dandruff and seborrheic dermatitis. Am J Res Commun. 2013;1(8):63-80. 